\title{
Research on the Development Path of Newly Established Undergraduate Colleges Based on the Perspective of Innovative Development of Higher Vocational Education
}

\author{
Jiajia Wang ${ }^{1, a}$, Yu Chen ${ }^{1, b}$ \\ ${ }^{1}$ Taizhou Polytechnic College, Jiangsu Taizhou, China, 225300 \\ awangjiajia_99@163.com, b38907447@qq.com
}

Keywords: higher vocational education, innovation and development, location of running a school, undergraduate higher vocational, path exploration

\begin{abstract}
The development of vocational education at undergraduate level, is the call of the times, also is the inevitable choice to break "dead end highway" for higher vocational education. Newly-established undergraduate colleges develop rapidly irresistible in this context, with a dispute. But they must always be clear and keep their position, their upgrading are based on the needs of the innovation and development of higher vocational education, only the objective laws of the development of vocational education and undergraduate education are closely integrated, actively crack down hard on the problems and dilemmas in development, we could really achieve sound and fast development.
\end{abstract}

\section{Introduction}

Newly-established undergraduate colleges, most of them are merged, restructured and upgraded by higher vocational colleges or adult colleges and universities, get their name by the very short period of implementation of undergraduate education. More than ten years, with the rapid development of China's higher education, newly-established undergraduate colleges also rose up, the number expanded rapidly, at present, accounting for $1 / 3$ of the national undergraduate colleges and universities and half of the local universities. Among them, there are always accompanied by strong contradictions and conflicts. On the one hand, the country rigid control higher vocational colleges rise to undergraduate schools. On the other hand, the higher vocational colleges have a strong appeal to rise to undergraduate schools. ${ }^{[1]}$ At the same time, with the development of higher vocational education, the problem of " dead end highway " also must be resolved, the birth and development of undergraduate higher vocational education is the trend and imperative of the times. May 2014, "The decision on accelerating the development of modern occupation education" issued by the State Council, expressly put forward "to explore the development of undergraduate level vocational education occupation". ${ }^{2]}$

To achieve this goal, the newly- established undergraduate colleges must take the responsibilities of "leading army" and "demonstration area", take to train high-quality technical personnel as their duty, running application-oriented undergraduate education, not only elegant to achieve "gorgeous transfiguration", but also perfect to achieve "transformation and upgrading". In the process, they should always understand and keep it in mind, their upgrading is based on the needs of the innovation and development of higher vocational education, is the upgrading of the school level, but not to put aside all the original and start again. In the final analysis, it changed from specialized vocational education into undergraduate vocational education, instead of getting rid of higher vocational education and do another, at the same time, according to the basic position and basic requirements of vocational education and undergraduate education, the objective laws of vocational education and the development of undergraduate education should be closely integrated, actively crack the difficulties and predicament in development, it is not only a very important force in the process of popularization of higher education, but also a powerful and influential type of vocational education in our country. 


\section{The main problems existing in the development of newly-established undergraduate colleges}

\subsection{The idea of development can not synchronous.}

The development idea of an university directly determines the orientation of the university itself and its pursuit of development goals, without clear and reasonable idea, it can not find the real coordinates and azimuth, more unlikely to get ideal results. The development idea and its actual ability can not be synchronized, that is a common problem in newly established undergraduate colleges. Although many newly established undergraduate colleges have raised their level, they can not locate themselves scientifically, overestimate their strength, blindly study to some veteran colleges, the idea of development is often too advanced.

\subsection{The system is not perfect.}

The system construction is the basic construction of the modern university. "Outline of the national program for medium and long term educational reform and development (2010-2020)" take "building modern university system" as a very important task for colleges and universities. ${ }^{[3]}$ Because of at a low level for a long time, the rules and regulations formed in the process of running school are congenitally deficient, it can not be updated and sound in time. At the same time, it often has its own set of customary management mode in the long running process, often these unwritten, unstable management mode is compensated for the lack of system construction, virtually hinder the regular and perfect the progress of the system.

\subsection{Teaching staff are not up to standard.}

Most colleges have made great efforts to import teachers and improved the quality of teachers in order to meet the set standards before they upgrade. The overall strength of the faculty is weak yet, it is still a common phenomenon, in particular, the level of education, teaching and thinking mode can not well adapt to undergraduate education. Although some high-level talents have been imported, the quantity is still relatively small, and the structure of knowledge and ability is not reasonable enough. Some people can only be said to be "high level talents" in the external conditions, eg educational background, professional title, etc, however, internal factors, eg ability, quality, etc are somewhat lacking, they are not the real "high level talents".

\subsection{Professional structure is not so reasonable.}

As a result of many factors, many colleges and universities mainly follow the original structure of professional settings, mend and perfect the traditional professional foundation. The advantage of this is that maintained the relative stability of professional construction. But the drawback is that the thinking of professional reform has great limitations, and the intensity of innovation can not be so great, what to do is in the old frame, the old routines, very difficult to have a substantive breakthrough and improvement, system planning must be strengthened, reforms should be carried out in accordance with the latest requirements of undergraduate education, strive to take professional construction as a leading factor, establish the internal logical relationship between specialities, lay a solid foundation for the professional comprehensive, coordinated, and sustainable development construction.

\subsection{Lack of initiative in learning.}

In order to truly complete the transformation and upgrading, the newly-established undergraduate colleges need to promote the ideas and understanding of the faculty and staff. Many colleges have raised their level of education, but the staff especially the former staff before upgraded whose awareness has not been effectively improved, it doesn't match the current level of education well. Many faculty members are content with the status quo and are used to continuing the mindset of the specialized period, follow the prescribed order, conservative, could not take the initiative to learn new knowledge, new requirements in an undergraduate course, and could not update their ideas and knowledge in time.

\subsection{Academic atmosphere is not strong enough.}

A lot of newly-established undergraduate colleges is relatively weak in the basis of academic research, together with affected by the inertia thinking in specialist schools, some teachers still can 
not meet the requirements of undergraduate education in their academic research consciousness, ability and accomplishment, not yet deeply realized: scientific research and teaching complement each other, without academic research, without studying the content of the course, it is impossible to teach the class well and thoroughly, it is impossible to become a qualified undergraduate teachers, it can not lead the students to embark on the road of inquiry, more unable to train high-quality technical and skill personnel.

\subsection{The management level is not compatible.}

A solid, orderly, efficient and smooth management is the basic prerequisite for the sound and fast development of colleges and universities. Some schools still use the previous management system, but with the rise of school level, great changes have taken place in management, especially the education, teaching management and internal management of the college, the specific scope, content and requirements are very different from before, management often appear in straitened circumstances. Especially in the vast majority of management personnel and backbone, all from the original school, thinking habits, work style and ability quality have no obvious change and improvement, the specific management work is also often powerless.

\subsection{Local service is not close enough.}

Many newly-established undergraduate colleges ignore the intensive study about the local industrial development and the social undertakings policy, in the professional setting and adjustment, personnel training, social services, skills training and other aspects docking can not be effective, seriously affected the support of local governments and enterprises. There are still some colleges, although upgraded, but can not recognize the position, can not identify the place in the local economic and social development, industry chain position, can not give full play to the standard and advantage of undergraduate colleges, and provide similar services with local vocational colleges and secondary vocational schools, even disrupt the battle, grab resources, and ultimately draw further apart the principle of serving the local.

\section{Path selection of newly-established undergraduate colleges development}

\subsection{Grasp top-level design, and prominent forward-looking.}

Newly-established undergraduate colleges should be based on their own environment, resources, their own strength, the source and whereabouts of students and other objective conditions, in accordance with national and provincial requirements for undergraduate education, rational thinking, careful planning, form of distinctive and unique top-level design in the guiding ideology for running a school, goal direction, personnel training mode, management system, construction of teachers, the training environment and other aspects, and for this reason lead to the transformation and development of the school. At the same time, the top-level design determines the strategic direction and tactical choice of the future development of the newly-established undergraduate colleges, and also guides the allocation of limited resources, it must be scientific and reasonable, with a strong forward-looking, not only could effectively guide the current development of the school, but also reserve enough space for future development.

\subsection{Grasp the system arrangement, and highlight the systematicness.}

Newly-established undergraduate colleges have broken through the existing school framework and ushered in a large number of new things, many jobs are groundbreaking, and no established rules and experience are available. With the school level upgrade, a lot of work on the surface does not change much, but in fact the content and requirements have already changed, some of the original system has been unable to meet the needs of running schools, we must keep pace with the time, make good arrangements for the system, and persist in practical and effective system to regulatory power, manage matters, manage the employee. On the one hand, we should seriously carding the existing regulations carefully in the school, in conjunction with the requirements of work and the spirit of superiors, we will promptly remove a batch, revise a batch, formulate a batch, and strictly implement these rules and regulations, and realize standardized management. On the other hand, in combination 
with the college's development goals and focal point of the work, we should gradually establish a scientific and rational incentive mechanism, fully mobilize the enthusiasm of the staff, and add strong internal driving force for development.

\subsection{Grasp the organizational framework, and highlight the scientific nature.}

Organization structure of university related to the school level, school form, party and government management, teaching management, alliance organization, operation mode and subject distribution etc, not only has the diversity but also has the complexity. In order to rapidly meet the requirements of undergraduate education, the newly-established undergraduate colleges must profound grasp the objective law of the undergraduate education, in accordance with the need for diversity and complexity, the existing organizational framework is reorganized in a timely manner. When reforming, we must adhere to the principle of maintaining good quality, giving priority to efficiency and running smoothly. We should fully preserve the scientific and rational parts of the original organizational framework and boldly discard the outdated ones, combined with the existing school scale, the new school running idea, the positioning of the school, the development strategy and other practical needs, timely revocation, merger, rename, reorganization of the relevant colleges, departments and research institutions, set up the organizational structure adapted to the development of colleges and universities.

\subsection{Grasp the team building, and prominent development.}

Comprehensively strengthen the team construction, speed up the construction of a high moral, excellent business, reasonable structure, full of vitality of high-quality professional teachers team, cadres team and logistics team, and give full play to their important role in teaching education, management education, and serving education, it is a very important and urgent task for the newly established undergraduate colleges. We must always remember the general secretary Xi Jinping's entrust "The teachers are the base on education, are the source of vitalize education, take responsibility to improve the people's satisfaction with education." In order to put the talents strengthening on the height of strategic development we should seriously study and formulate the construction planning of teaching staff, cadres and logistics staff in the new situation. Through school-based training, exercise attachment, go out to study and other initiatives, we effort to enhance the sustainable development ability of the original staff, promote their successful transformation and plan to enrich the forces of each team.

\subsection{Do a good job of personnel training, and give prominence to the application.}

Whether it is before upgraded or after upgraded, personnel training should be the most important task. But compared with the specialized education before upgrading, the connotation of undergraduate training has undergone profound changes, it has both commonness and individuality. For the newly established undergraduate colleges, the practical factors determine that they can not take the road of comprehensive universities and research universities, moreover, it is impossible to focus on scientific research and training research talents, and the best choice is to focus on the training of applied talents. The newly established undergraduate colleges should quickly shake off the thinking mode of "practical" talents training in the period of higher vocational education, and highlight the "application" in the process of personnel training, more attention should be paid to the mutual penetration and integration of theory and practice, so as to the quality of personel tranning meet the standards of undergraduate education as soon as possible, and gradually form their own characteristics and brands.

\subsection{Do a good job of cultural construction, and give prominence to distinctive features.}

Culture as a kind of spiritual strength in leading and playing an irreplaceable role in promoting the development of the university. The newly established undergraduate colleges must pay attention to cultural construction and endow themselves with distinctive "new souls". Of course, the formation of any kind of excellent culture is not the "castles in the air" which is divorced from reality, but should be integrated into the connotation of the times and fresh nutriment on the basis of inheriting and carrying forward the tradition. Many newly-established undergraduate colleges after upgrading, ignore their own "soil", "background" and "film", blindly cloning other people's cultural genes, 
leading to lack of characteristics or converge characteristics, exacerbated the phenomenon of "thousands of schools share with one side", we must learn a lesson. Always adhere to everything from reality, based on both the school's tradition and reality, and the external outstanding cultural achievements, continuous exploration and innovation, bring forth the new through the old, and actively build the unique university culture that in line with the law of education development, and conducive to their own survival and development, lasting, stable.

3.7 Do a good job in social services, and highlight locality.

Most of the newly-established undergraduate colleges are provincial and municipal co management, with the city orientation, we should firmly establish the concept of "learning must be in use, and must be used properly", and strive for development in the service, acquire resources in contribution. We must adhere to the dislocation development and avoid homogenization competition with various schools: First, we should fully embody the concept of local service and take the "mainly for local talent training" as the fundamental task, take the initiative to adapt to the local culture and education, economic construction and industrial development, boldly close cooperate with local governments, enterprises and institutions, set up disciplines and majors that the local need badly, to cultivate a large number of high quality applied talents for places to go to grass-roots, be able to stay, and come in handy; Two, we should formulate and improve relevant policies to promote teachers to be close to the government departments and enterprises, undertake more important issues that the government urgently needs to crack and the technical problems that enterprises urgently need to solve, and cooperate with innovative forms, form a strategic alliance with other universities in this region, collaborative innovation, cooperative tackle key problems, and effectively improve service level.

\section{Acknowledgements}

This work was financially supported by the Institute of Taizhou Polytechnic College Research Project (Research on Testing Technology of Penetration, TZYKY-15-7).

\section{References}

[1] Yu Chen, Jiajia Wang. Three key points about the development of Higher Vocational Education[J], Advances in Economics, Business and Management Research, April 2017.

[2] The Sate Council. Decision of the State Council on speeding up the development of modern vocational education[Z], States made, [2014]NO.19.

[3] The Central Committee of the CPC, the State Council. Outline of the national program for medium and long term educational reform and development(2010-2020 year)[N], Guang Ming Daily, 2010-7-30(1). 